\title{
Effect of $P$. serratifolia Leaf Extract on Hematological Parameters and Standarization of Snacks using P. serratifolia Leaf Powder
}

\author{
K. Kaviya and S. Ponne \\ Department of Foods and Nutrition, Vellalar College for Women, Erode - 638012, Tamil Nadu, India; \\ Kaviyakrishnamoorthy666@gmail.com
}

\begin{abstract}
Premna serratifolia (also known as Pachumullai) belongs to the family Verbenaceae, is a medicinal plant known as Agnimantha in Ayurveda. It has potential hepatoprotective and cytotoxic activity. There are many phytochemical and bioactive compounds present in the plant parts of Premna serratifolia. In addition to this, it has higher antioxidant and antimicrobial activity which is beneficial to human health as a therapeutic adjuvant. However, the nutritional components in P. serratifolia have not been probed, though it was consumed during special rituals. Further the anti-anemic effect of $P$. serratifolia was not yet studied. The present research aimed at assessing the micronutrients (Iron, Phosphorus, Calcium, Ascorbic acid) in P. serratifolia leaf, and the ethanolic extract of $P$. serratifolia leaf at two different dosage $(100 \mathrm{mg}$ and $200 \mathrm{mg}$ ) was examined for hematological parameters (Hemoglobin, Red Blood Cell count and Mean Corpuscular Hemoglobin) in anemic rats and the value added snacks like biscuit, vadam and murukku were formulated at two different ratios by using $P$. serratifolia leaf powder. The results showed that $P$. serratifolia leaf extract had higher impact on the hematological parameters when compared with standard drug ferrous fumarate and the higher incorporation of $P$. serratifolia leaf powder helped to increase the nutrient content in formulated snacks.
\end{abstract}

Keywords: Anti-Anemic, Ethanolic Extract, Ferrous Fumarate, P. serratifolia, Value Added Snacks

\section{Introduction}

India has the world's highest prevalence of iron deficiency anemia among women, with 60 to 70 percent of the adolescent girls being anemic ${ }^{1}$. Anemic condition tends to have negative impact on physical performance, mostly work productivity due to reduced oxygen transport ${ }^{2}$. The first victim of lifestyle changes has been food habits. Consumption of junk food has increased manifold, which has led to a number of diseases related to nutritional deficiencies, and nutraceuticals play an important role in controlling them ${ }^{3}$. A term combining the words nutrition (a nourishing food or food component) and Pharmaceutical (a medical drug) is a food or food product that provides health and medical benefits, including the prevention and treatment of diseases ${ }^{4}$.

India is endowed with an estimated 47,000 species of plant that include around 8000 plants which are known to have medicinal properties 5 . Among various medicinal plants Premna serratifolia is one of the medicinal plant belonging to the family of verbenaceae also known as Agnimantha in Ayurvedha. It is a large shrub or a small tree up to $9 \mathrm{~m}$ in height with yellowish lenticulate bark, spinous large branches and yellowish brown woody aromatic root, leaves, simple, opposite, sometimes whorled, elliptic ovate ${ }^{6}$. 
The GC-MS chromatogram shows the presence of 22 major peaks with the retention time ranging between 2.72 and 34.54. The nature of the compounds obtained are of monoterpene oxide, monoterpene alcohol, sesquiterpene, terpene alcohol, alcoholic compound, perpionate compound, linolenic acid ester, diterpene, acetate compound, alkene compound, triterpene, unsaturated fatty acid ester, vitamin compound, ketone compound and acetate compound ${ }^{\mathrm{T}}$.

The leaf extract of $P$. serratifolia was most susceptible anti microbes like Klebsiella pneumoniae, Streptococcus epidermidis and Pseudomonas aeruginosa ${ }^{8}$.

The alcoholic extract of $P$. serratifolia leaf has hepatoprotective activity against carbon tetrachloride induced hepatotoxicity in rats. According to Selvam et al $l^{9}$, the methanolic extract of $P$. serratifolia leaf has tumor cell suppression potential in 3 different cancer cell lines - breast cancer (MCF7), liver cancer (Hepg2), and lung cancer (A549) than the standard drug adriamycin.

\section{Materials and Methods}

\subsection{Determination of Nutrient Content in $\boldsymbol{P}$. serratifolia Leaf}

P. serratifolia leaf was analysed for the micronutrients like Iron, phosphorus, calcium, ascorbic acid by using the standard procedures.

\subsection{Processing and Preparation of Plant Extract}

Fresh leaves of $P$. serratifolia were collected in the month of October to December from Erode and Karur district of Tamilnadu and used for the study. Cleaned fresh leaves were shade dried for 3-4 days and powdered. By using ethanol the air dried powder was concentrated, evaporated to dryness until semi solid masses was obtained.

\subsection{Experimental Design for Animal Study}

Healthy twenty eight days old albino Wister rats weighing about 100-200 g were used for the study. The rats were divided into five groups consisting of five animals in each group (Table 1).

\subsection{Body Weight Measurements}

The rats in each group were weighed on the initial day, $7^{\text {th }}$, $14^{\text {th }}$ and $21^{\text {st }}$ day and their weights were recorded.

\subsection{Biochemical Examination of the Rats}

About $1 \mathrm{ml}$ of blood was collected from each rat by Tail vein method at 7 days interval for a period of 21 days. Local anesthesia was applied to the rats before drawing the blood. After collecting the blood sample, silver nitrate ointment solution was applied to stop the bleeding and the blood samples were used for assessing the hematological parameters on the initial day, $7^{\text {th }}, 14^{\text {th }}$ and $21^{\text {st }}$ day.

Table 1. Animal groups $(\mathrm{N}=5)$

\begin{tabular}{|c|c|c|}
\hline Animal grouping & Drug treatment & Dosage treatment \\
\hline Group 1 & Normal control & Standard feed \\
\hline Group 2 & Anemic control & $\begin{array}{c}\text { Anemic condition with standard } \\
\text { feed }\end{array}$ \\
\hline Group 3 & Standard control & $\begin{array}{c}\text { Ferrous fumarate } \\
0.23 \mathrm{mg} / \mathrm{kg}\end{array}$ \\
\hline Group 4 & Leaf extract dosage 1 & $100 \mathrm{mg} / \mathrm{kg}$ \\
\hline Group 5 & Leaf extract dosage 2 & $200 \mathrm{mg} / \mathrm{kg}$ \\
\hline
\end{tabular}


Hemoglobin estimation was done by using Sahli's method and Red Blood Cell count was done by using Neubauer chamber method.

After determining, $\mathrm{Hb}$ and $\mathrm{RBC}$, Mean Corpuscular hemoglobin $(\mathrm{MCH})$ was calculated, by using the following equation

$$
\mathrm{MCH}(\mathrm{Pg})=[\mathrm{Hb}(\mathrm{gm} \%) \mathrm{x} 10] /[\mathrm{RBC}(\mathrm{cm} . \mathrm{mm})]
$$

\subsection{Preparation of Value Added Biscuit using $P$. serratifolia Leaf Powder}

Proportions of ingredients used in value added biscuit is presented in Table 2.

Mix all ingredients into a dough by adding little amount of water, rolled and then cut into a desired shapes and fried in oil till golden brown colour was obtained.

\subsection{Preparation of Value Added Rice Vadam using $P$. serratifolia Leaf Powder}

The ingredients used in the preparation of value added rice vadam is presented in Table 3.
Grind Green chilly with rice flour and mix well by adding salt and water. Mix the leaf powder into the rice batter at desired proportion and cumin seeds, and then allow it to stand for overnight. Then steam cooked for 10-20 mints, molded into shapes, and sun dried for 1-2 days and then fried in oil.

\subsection{Preparation of Value Added Murukku by using $P$. serratifolia Leaf Powder}

The ingredients used in the preparation of value added Murukku is presented in Table 4.

Mix rice flour and roasted Bengal gram flour by adding salt and sesame seeds.

Make into a dough by adding little amount of water, then shaped by using a mould and fried in oil still golden brown colour.

\subsection{Organoleptic Evaluation of $P$. serratifolia Leaf Powder Incorporated Products}

The formulated recipes were organoleptically evaluated to estimate their acceptability like appearance, flavor, taste,

Table 2. Proportion of ingredients used in value added biscuit

\begin{tabular}{|c|c|c|c|c|}
\hline \multirow{2}{*}{ S.No } & \multirow{2}{*}{ Ingredients } & \multicolumn{3}{|c|}{ Weight In Grams } \\
\cline { 3 - 5 } & & Standard Biscuit & \multicolumn{2}{|c|}{ Leaf Powder Incorporated Biscuit } \\
\cline { 3 - 5 } & & $\mathbf{S}$ & $\mathbf{S}_{1}$ & $\mathbf{S}_{2}$ \\
\hline 1 & Wheat flour & 250 & 250 & 250 \\
\hline 2 & Ghee & 2 tsp & 2 tsp & 2 tsp \\
\hline 3 & Leaf powder & - & 12.5 & 25 \\
\hline 4 & Chili powder & as required & as required & as required \\
\hline 5 & Salt & as required & as required & as required \\
\hline 6 & Oil & to fry & to fry & to fry \\
\hline
\end{tabular}

S - Standard; $\mathbf{S}_{1}-10: 0.5$ (Wheat flour: P. serratifolia leaf powder);

$S_{2}-10: 1$ (Wheat flour: P. serratifolia leaf powder). 
Table 3. Proportion of ingredients used in value added rice vadam

\begin{tabular}{|c|c|c|c|c|}
\hline \multirow{2}{*}{ S.No } & \multirow{2}{*}{ Ingredients } & \multicolumn{3}{|c|}{ Weight In Grams } \\
\cline { 3 - 5 } & & $\begin{array}{c}\text { Standard Vadam } \\
\text { S }\end{array}$ & Leaf Powder Incorporated Vadam \\
\cline { 3 - 5 } & & 100 & S1 & S2 \\
\hline 1 & Rice flour & 2 No & 2 No & 2 No \\
\hline 2 & Green chilly & - & 100 & 20 \\
\hline 3 & Leaf powder & 1 tsp & 1 tsp & 1 tsp \\
\hline 4 & Cumin seeds & as required & as required & as required \\
\hline 5 & Salt & to fry & to fry & to fry \\
\hline 6 & Oil & &
\end{tabular}

S - Standard vadam; $\mathbf{S}_{1}-10: 1$ (Rice flour : P.serratifolialeaf powder);

$\mathbf{S}_{2}-10: 2$ (Rice flour: P.serratifolialeaf powder).

Table 4. Proportion of ingredients used in value added murukku

\begin{tabular}{|c|c|c|c|c|}
\hline \multirow{3}{*}{ S.No } & \multirow{3}{*}{ Ingredients } & \multicolumn{3}{|c|}{ Weight In Grams } \\
\hline & & \multirow{2}{*}{$\begin{array}{c}\text { Standard Murukku } \\
\text { S }\end{array}$} & \multicolumn{2}{|c|}{ Leaf Powder Incorporated Murukku } \\
\hline & & & $S_{1}$ & $\mathrm{~S}_{2}$ \\
\hline 1 & Rice flour & 200 & 200 & 200 \\
\hline 2 & $\begin{array}{c}\text { Roasted Bengal gram } \\
\text { flour }\end{array}$ & 50 & 50 & 50 \\
\hline 3 & Ghee & 2 tsp & 2 tsp & 2 tsp \\
\hline 4 & Leaf powder & - & 12.5 & 25 \\
\hline 5 & Cumin seeds & $1 \mathrm{tsp}$ & 1 tsp & $1 \mathrm{tsp}$ \\
\hline 6 & Chili powder & as required & as required & as required \\
\hline 7 & Salt & as required & as required & as required \\
\hline 8 & Oil & to fry & to fry & to fry \\
\hline
\end{tabular}

S - Standard; $\mathbf{S}_{1}-10: 0.5$ (Rice flour: P.serratifolialeaf powder);

$S_{2}-10: 1$ (Rice flour: Pserratifolialeaf powder).

texture, colour. Organoleptic evaluation was carried out

by numerical score card method by using 25 semi trained panel members. 


\subsection{Computation of Nutritive Value for Formulated Snacks using $P$. serratifolia Leaf Powder}

Comparison of nutrients like iron, phosphorous, calcium, ascorbic acid for the standard and formulated snacks using P. serratifolia leaf powder were calculated based on the ICMR requirement (2011).

\section{Results and Discussion}

\subsection{Determination of Nutrient Content in $P$. serratifolia Leaf}

Green leafy vegetables are mostly rich in micro nutrients, hence micronutrients such as iron, phosphorous, calcium and vitamin $\mathrm{C}$ were determined in P. serratifolia Leaf.

The mean iron content (Table 5) of P. serratifolia leaf was $35 \pm 2.03 \mathrm{mg} / 100 \mathrm{~g}$ which is comparable with the iron content of amaranth (tristis) - 38.5mg/100 and cauliflower leaves $-40.0 \mathrm{mg} / 100 \mathrm{~g}$. Though the iron content is high in $P$. serratifolia leaf, it remains underutilized due to lack of awareness and lack of popularity.

The mean phosphorus content of $P$. serratifolia leaf was $34.66 \pm 3.83 \mathrm{mg} / 100 \mathrm{~g}$ and the mean calcium content
Table 5. Nutrient content of $P$. serratifolia leaf (100g)

\begin{tabular}{|c|c|}
\hline Nutrients & $\begin{array}{c}\text { Mean } \pm \text { SD } \\
(\mathrm{mg})\end{array}$ \\
\hline Iron & $35.0 \pm 2.03$ \\
\hline Phosphorus & $34.66 \pm 3.83$ \\
\hline Calcium & $18.53 \pm 0.32$ \\
\hline Ascorbic Acid & $31.33 \pm 0.97$ \\
\hline
\end{tabular}

of $P$. serratifolia leaf was $18.53 \pm 0.32 \mathrm{mg} / 100 \mathrm{~g}$. The mean ascorbic acid content of $P$. serratifolia leaf was $31.33 \pm$ $0.97 \mathrm{mg} / 100 \mathrm{~g}$.

\subsection{Body Weight Changes in Experimental Rats}

\subsubsection{Effect of P. serratifolia Leaf Extract on the Body Weight of Experimental Animals}

During 21 days study period, the body weights of selected animal groups were assessed and listed in Table 6.

Table 5. Effect of P. serratifolia leaf extract on the body weight of experimental animals

\begin{tabular}{|c|c|c|c|c|c|}
\hline \multirow{2}{*}{ Drug treatment } & \multirow{2}{*}{ Dosage } & \multicolumn{4}{|c|}{ Mean \pm SD } \\
\cline { 3 - 6 } & & \multicolumn{3}{|c|}{ Body weight $(\mathbf{g})$} \\
\cline { 3 - 6 } & & $\mathbf{1}^{\text {st }}$ day & $7^{\text {th }}$ day & $\mathbf{1 4}^{\text {th }}$ day & $\mathbf{2 1}^{\text {st }}$ day \\
\hline $\begin{array}{c}\text { G1 } \\
(\mathrm{n}-5)\end{array}$ & Standard Pellet & $168 \pm 2.56$ & $173.6 \pm 2.70$ & $178.8 \pm 3.21$ & $183.6 \pm 2.41$ \\
\hline $\begin{array}{c}\text { G2 } \\
(\mathrm{n}-5)\end{array}$ & Standard Pellet & $149.8 \pm 2.8$ & $148.4 \pm 3.32$ & $147.6 \pm 3.59$ & $148 \pm 2.82$ \\
\hline $\begin{array}{c}\text { G3 } \\
(\mathrm{n}-5)\end{array}$ & $\begin{array}{r}0.23 \mathrm{mg} / \mathrm{kg} \\
\text { G4 }\end{array}$ & $149.8 \pm 3.49$ & $140 \pm 2.47$ & $196.4 \pm 3.33$ & $218.8 \pm 2.16$ \\
\hline$(\mathrm{n}-5)$ & Extract $100 \mathrm{mg} / \mathrm{kg}$ & $123.2 \pm 2.9$ & $108.8 \pm 2.99$ & $121.2 \pm 4.25$ & $126 \pm 5.95$ \\
\hline $\begin{array}{c}\text { G5 } \\
(\mathrm{n}-5)\end{array}$ & Extract $200 \mathrm{mg} / \mathrm{kg}$ & $131.4 \pm 2.68$ & $127.8 \pm 2.8$ & $146.8 \pm 3.34$ & $154.2 \pm 3.37$ \\
\hline
\end{tabular}

G1 - Normal control, G2 - Anemic control, G3 - Standard drug control, G4 - Dosage 1, G5 - Dosage 2 
It is evident from Table 6 that body weight of G1 gradually increased whereas the body weight of G2 decreased during the study period after phenylhydrazine administration. Due to regular intake of standard drug ferrous fumarate the body weight of the animal showed maximum increase in body weight compared to the other experimental groups. P. serratifolia leaf extract administrated in two dosages also increased the body weight of the experimental rats. Further, it was noted that the increase in body weight was more in G5 administered animals than G4.

\subsubsection{Comparison of Body Weight Changes on Experimental Animal Groups}

The comparison of body weight changes of animal groups before and after supplementation is given in Table 7 .

From the Table 7 it is noted that except G2, all other groups showed significant difference. G3 showed significant difference at 5 per cent level between initial and $7^{\text {th }}$, $14^{\text {th }}$ and $21^{\text {st }}$ day of supplementation. In the groups G4 and G5, which received extract of $P$. serratifolia in two different dosages showed a significant at 1 per cent level between initial and $7^{\text {th }}, 14^{\text {th }}$ and $21^{\text {st }}$ day of the study.

\subsubsection{Comparison of Body Weight Changes between the Groups}

The comparison of body weight changes between the animal grouping are listed in the Table 8 .

From the Table 8 it was noted that when G3 supplemented group was compared with G2, statistical analysis showed a significant difference at 1 per cent level from $14^{\text {th }}$ day onwards. In G4 and G5 groups supplementation with $P$. serratifolia at two different dosages, both the groups showed significant increase in body weight from $7^{\text {th }}$ day onwards.

\subsection{Hematological Parameters}

\subsubsection{Hemoglobin Level of Experimental Animals}

The hemoglobin levels were assessed on the $1^{\text {st }}, 7^{\text {th }}, 14^{\text {th }}$, and $21^{\text {st }}$ day and the values are shown in the Figure 1.

It is evident that hemoglobin level reduced when phenyl hydrazine was induced on the animal groups except G1. The hemoglobin levels in G1 were maintained at normal range. When standard drug and extract (dosage 1 and

Table 7. Comparison of body weight changes in experimental animal groups after supplementation

\begin{tabular}{|c|c|c|c|c|c|}
\hline \multirow{2}{*}{ Days } & \multicolumn{5}{|c|}{ Drug treatment } \\
\cline { 2 - 6 } & $\begin{array}{c}\text { G1 } \\
(\mathrm{n}-5)\end{array}$ & $\begin{array}{c}\text { G2 } \\
(\mathrm{n}-5)\end{array}$ & $\begin{array}{c}\mathrm{G} 3 \\
(\mathrm{n}-5)\end{array}$ & $\begin{array}{c}\mathrm{G} 4 \\
(\mathrm{n}-5)\end{array}$ & $\begin{array}{c}\mathrm{G} 5 \\
(\mathrm{n}-5)\end{array}$ \\
\hline $\begin{array}{c}\text { Between and } 1^{\text {st }} \\
\text { and } 7^{\text {th }} \text { day }\end{array}$ & $3.58^{*}$ & $0.31^{\mathrm{NS}}$ & $3.94^{*}$ & $4.17^{*}$ & $3.61^{*}$ \\
\hline $\begin{array}{c}\text { Between and } 1^{\text {st }} \\
\text { and } 14^{\text {th }} \text { day }\end{array}$ & $6.63^{* *}$ & $1.05^{\mathrm{Ns}}$ & $4.10^{*}$ & $5.46^{* *}$ & $6.84^{* *}$ \\
\hline $\begin{array}{c}\text { Between and } 1^{\text {st }} \\
\text { and } 21^{\text {st }} \text { day }\end{array}$ & $6.70^{* *}$ & $0.81^{\mathrm{NS}}$ & $4.58^{*}$ & $6.43^{* *}$ & $10.68^{* *}$ \\
\hline
\end{tabular}

G1 - Normal control, G2 - Anemic control, G3 - Standard drug control, G4 - Dosage 1, G5 - Dosage 2

NS - not significant, ${ }^{\star}-5$ per cent level significant, ${ }^{* *}-1$ per cent level significant 
Table 8. Comparison of body weight between the experimental animals [N=20]

\begin{tabular}{|c|c|c|c|c|}
\hline \multirow{2}{*}{ Animal groups } & \multicolumn{3}{|c|}{ Days of supplementation } \\
\cline { 2 - 5 } & $1^{\text {st }}$ & $7^{\text {th }}$ & $14^{\text {th }}$ & $21^{\text {st }}$ \\
\hline \multirow{2}{*}{ G2 vs G3 } & $0.01^{\mathrm{NS}}$ & $0.49^{\mathrm{NS}}$ & $4.95^{* *}$ & $6.45^{* *}$ \\
\hline \multirow{2}{*}{ G2 vs G4 } & $1.99^{\mathrm{NS}}$ & $3.29^{*}$ & $3.59^{*}$ & $4.17^{*}$ \\
\hline \multirow{2}{*}{$\mathrm{G} 2$ vs G5 } & $1.49^{\mathrm{NS}}$ & $3.68^{*}$ & $4.06^{*}$ & $4.55^{*}$ \\
\hline
\end{tabular}

G1 - Normal control, G2 - Anemic control, G3 - Standard drug control, G4 - Dosage 1,

G5 - Dosage 2

NS - not significant, ${ }^{\star}-5$ per cent level significant, ${ }^{* *}-1$ per cent level significant

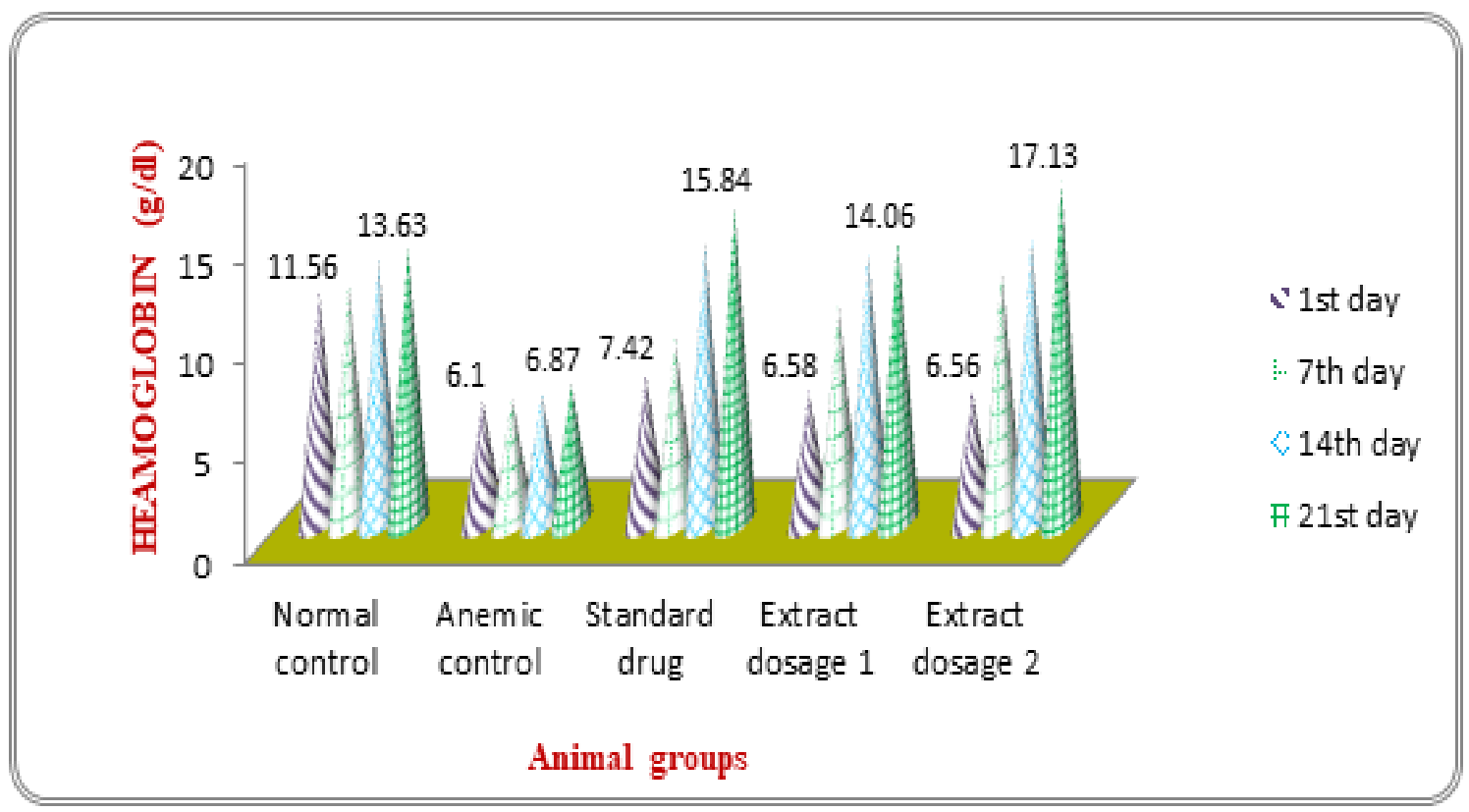

Figure 1. Effect of $P$. serratifolia leaf extract on Hemoglobin of experimental animals.

2) were given daily there was a gradual increase in the hemoglobin content. G5 showed greater improvement in hemoglobin level followed by G3 and G4. In G2, the hemoglobin content was maintain below the normal range after $21^{\text {st }}$ day.

\subsubsection{Comparison of Haemoglobin in Experimental Animals after Supplementation}

It is evident from Table 9 that the hemoglobin levels of G1 and G2 did not show any significant difference between 
Table 9. Comparison of hemoglobin levels in experimental animals after supplementation

\begin{tabular}{|c|c|c|c|c|c|}
\hline \multirow{2}{*}{ Days } & \multicolumn{5}{|c|}{ Drug treatment } \\
\cline { 2 - 6 } & $\begin{array}{c}\text { G1 } \\
(\mathrm{n}-5)\end{array}$ & $\begin{array}{c}\text { G2 } \\
(\mathrm{n}-5)\end{array}$ & $\begin{array}{c}\text { G3 } \\
(\mathrm{n}-5)\end{array}$ & $\begin{array}{c}\mathrm{G} 4 \\
(\mathrm{n}-5)\end{array}$ & $\begin{array}{c}\mathrm{G} 5 \\
(\mathrm{n}-5)\end{array}$ \\
\hline $\begin{array}{c}\text { Between and } 1^{\text {st }} \\
\text { and } 7^{\text {th }} \text { day }\end{array}$ & $1.87^{\mathrm{NS}}$ & $2.75^{\mathrm{NS}}$ & $4.23^{*}$ & $3.46^{*}$ & $4.08^{*}$ \\
\hline $\begin{array}{c}\text { Between and } 1^{\text {st }} \\
\text { and } 14^{\text {th }} \text { day }\end{array}$ & $4.24^{*}$ & $2.30^{\mathrm{NS}}$ & $13.36^{*}$ & $12.44^{* *}$ & $20.70^{* *}$ \\
\hline $\begin{array}{c}\text { Between and } 1^{\text {st }} \\
\text { and } 21^{\text {st }} \text { day }\end{array}$ & $4.91^{* *}$ & $4.90^{* *}$ & $26.93^{*}$ & $15.93^{* *}$ & $29.06^{* *}$ \\
\hline
\end{tabular}

G1 - Normal control, G2 - Anemic control, G3 - Standard drug control, G4 - Dosage 1, G5 - Dosage 2

NS - not significant, ${ }^{\star} \quad-5$ per cent level significant, ${ }^{\star *}-1$ per cent level significant

$1^{\text {st }}$ and $7^{\text {th }}$ day of supplementation, whereas in rats supplemented with ferrous fumarate and $P$. serratifolia in two dosage statistical analysis revealed significant difference at 5 per cent level. Further statistical analysis showed significant difference between initial and $14^{\text {th }}$ day in G1 at 5 per cent level and G2 did not show any significant difference between $1^{\text {st }}$ and $14^{\text {th }}$ day. In rats supplemented with standard drug and $P$. serratifolia in two dosages, significant difference was noted at 1 per cent in all groups between $1^{\text {st }}$ and $14^{\text {th }}$ day of supplementation. In all the groups significant difference was noted in haemoglobin between $1^{\text {st }}$ and $21^{\text {st }}$ day of the supplementation.

\subsubsection{Red Blood Cell Count of Experimental Animals}

Red Blood Cell count was assessed on the initial day and at $7^{\text {th }}, 14^{\text {th }}, 21^{\text {st }}$ days interval for a period of 21 days and the

Table 10. Effect of P. serratifolia Leaf Extract on RBC Levels in Experimental Animals

\begin{tabular}{|c|c|c|c|c|c|}
\hline \multirow{3}{*}{ Drug treatment } & \multirow{3}{*}{ Dosage } & \multicolumn{4}{|c|}{ Mean \pm SD } \\
\hline & & \multicolumn{4}{|c|}{ Red Blood Cell (cells/cumm) } \\
\hline & & $1^{\text {st }}$ day & $7^{\text {th }}$ day & $14^{\text {th }}$ day & $21^{\text {st }}$ day \\
\hline $\begin{array}{c}\text { G1 } \\
(n-5)\end{array}$ & Standard Pellet & $6.74 \pm 0.26$ & $6.50 \pm 0.48$ & $6.97 \pm 0.22$ & $7.62 \pm 0.37$ \\
\hline $\begin{array}{c}\text { G2 } \\
(n-5)\end{array}$ & Standard Pellet & $3.07 \pm 0.10$ & $3.13 \pm 0.04$ & $3.21 \pm 0.03$ & $3.29 \pm 0.08$ \\
\hline $\begin{array}{c}\text { G3 } \\
(n-5)\end{array}$ & $\begin{array}{l}\text { Ferrous Fumarate } \\
0.23 \mathrm{mg} / \mathrm{kg}\end{array}$ & $3.43 \pm 0.45$ & $4.77 \pm 0.53$ & $6.84 \pm 0.29$ & $7.89 \pm 0.15$ \\
\hline $\begin{array}{c}\mathbf{G 4} \\
(\mathrm{n}-5)\end{array}$ & Extract $100 \mathrm{mg} / \mathrm{kg}$ & $3.51 \pm 0.41$ & $5.15 \pm 1.04$ & $7.39 \pm 0.27$ & $7.83 \pm 0.31$ \\
\hline $\begin{array}{c}\text { G5 } \\
(n-5)\end{array}$ & Extract $200 \mathrm{mg} / \mathrm{kg}$ & $3.59 \pm 0.70$ & $6.95 \pm 0.19$ & $7.17 \pm 0.35$ & $8.85 \pm 0.19$ \\
\hline
\end{tabular}

G1 - Normal control, G2 - Anemic control, G3 - Standard drug control, G4 - Dosage 1, G5 - Dosage 2 
results are listed in Table 10.

It is evident that G4 and G5 had higher response to retain the normal range of $\mathrm{RBC}$ than $\mathrm{G} 3$. The regular administration of standard drug and extract in two different dosages increased the red blood cell count gradually and the G5 showed higher response compared with G4 on retaining the normal range of $\mathrm{RBC}$ from anemic status. In $\mathrm{G} 2$ the increase in $\mathrm{RBC}$ was slow but the range was below the normal level even after 21 days of the study period.

\subsubsection{Comparison of RBC Count of Experimental Animals}

The comparison of $\mathrm{RBC}$ count of the experimental animals between initial and every $7^{\text {th }}$ day interval up to 21 days is given in Table 11.

From the above Table 11 it is evident that G1, G2 and G3 did not show any significant difference between initial and $7^{\text {th }}$ day of supplementation, whereas G4 showed significant difference at 5 per cent level and G5 at 1 per cent level. Further comparison of RBC count between $1^{\text {st }}$ and $14^{\text {th }}$ day reveled significant difference in G1, G3, G4 and G5 statistically, however the significant different was not evident in G2. The comparison of RBC count between $1^{\text {st }}$ day and $21^{\text {st }}$ day revealed significant difference in all the groups at 1 per cent level and in G2 at 5 per cent level.

\subsubsection{Mean Corpuscular Haemoglobin Status of Experimental Animals}

On selected animal groups the Mean Corpuscular Hemoglobin values were

calculated by using hemoglobin value and RBC count at 7 day interval for a period of 21 days and the values are listed in Table 12.

It is evident that all the experimental group had normal range of $\mathrm{MCH}$ value. In G3, G4 and G5 after inducing anemic, the regular administration of standard drug and leaf extract increased $\mathrm{MCH}$ in the 3 groups. The mean values for G3 was higher than G4 and G5 on $21^{\text {st }}$ day. There was a gradual increase in $\mathrm{MCH}$ values in all the drug treated animals.

\subsection{Comparison of Overall Acceptability Scores of Standards and Formulated Snacks using $P$. serratifolia Leaf Powder}

Table 13 represents the comparison of overall acceptability scores of the formulated snacks using $P$. serratifolia leaf powder.

From the Table 13, it is evident that among the standard snacks, vadam received the highest score followed by stan-

Table 11. Comparison of RBC count of experimental animals

\begin{tabular}{|c|c|c|c|c|c|}
\hline \multirow{2}{*}{ Days } & \multicolumn{5}{|c|}{ Drug treatment } \\
\cline { 2 - 6 } & $\begin{array}{c}\text { G1 } \\
(\mathrm{n}-5)\end{array}$ & $\begin{array}{c}\text { G2 } \\
(\mathrm{n}-5)\end{array}$ & $\begin{array}{c}\mathrm{G} 3 \\
(\mathrm{n}-5)\end{array}$ & $\begin{array}{c}\mathrm{G} 4 \\
(\mathrm{n}-5)\end{array}$ & $\begin{array}{c}\mathrm{G} 5 \\
(\mathrm{n}-5)\end{array}$ \\
\hline $\begin{array}{c}\text { Between and } 1^{\text {st }} \\
\text { and } 7^{\text {th }} \text { day }\end{array}$ & $1.96^{\mathrm{NS}}$ & $1.67^{\mathrm{NS}}$ & $1.92^{*}$ & $3.32^{*}$ & $12.45^{* *}$ \\
\hline $\begin{array}{c}\text { Between and } 1^{\text {st }} \\
\text { and } 14^{\text {th }} \text { day }\end{array}$ & $4.23^{*}$ & $2.60^{\mathrm{NS}}$ & $12.22^{* *}$ & $14.42^{* *}$ & $10.18^{* *}$ \\
\hline $\begin{array}{c}\text { Between and } 1^{\text {st }} \\
\text { and } 21^{\text {st }} \text { day }\end{array}$ & $7.80^{* *}$ & $4.08^{*}$ & $26.11^{*}$ & $16.05^{* *}$ & $21.28^{* *}$ \\
\hline
\end{tabular}

G1 - Normal control, G2 - Anemic control, G3 - Standard drug control, G4 - Dosage 1, G5 - Dosage 2

NS - not significant, ${ }^{*}-5$ per cent level significant, ${ }^{* *}-1$ per cent level significant 
Table 12. Effect of $P$. serratifolia leaf extract on $\mathrm{MCH}$ levels in experimental animals

\begin{tabular}{|c|c|c|c|c|c|}
\hline \multirow{3}{*}{ Drug treatment } & \multirow{3}{*}{ Dosage } & \multicolumn{4}{|c|}{ Mean \pm SD } \\
\hline & & \multicolumn{4}{|c|}{ Mean Corpuscular Haemoglobin (pg) } \\
\hline & & $1^{\text {st }}$ day & $7^{\text {th }}$ day & $14^{\text {th }}$ day & $21^{\text {st }}$ day \\
\hline $\begin{array}{c}\text { G1 } \\
(n-5)\end{array}$ & Standard Pellet & $14.36 \pm 1.07$ & $16.33 \pm 1.16$ & $18.06 \pm 0.63$ & $18.43 \pm 1.01$ \\
\hline $\begin{array}{c}\text { G2 } \\
(n-5)\end{array}$ & Standard Pellet & $16.39 \pm 1.52$ & $17.72 \pm 1.70$ & $18.99 \pm 1.80$ & $20.97 \pm 1.15$ \\
\hline $\begin{array}{c}\text { G3 } \\
(n-5)\end{array}$ & $\begin{array}{c}\text { Ferrous Fumarate } \\
0.23 \mathrm{mg} / \mathrm{kg}\end{array}$ & $18.44 \pm 3.68$ & $17.36 \pm 1.26$ & $19.48 \pm 0.80$ & $20.23 \pm 0.47$ \\
\hline $\begin{array}{c}\text { G4 } \\
(n-5)\end{array}$ & Extract $100 \mathrm{mg} / \mathrm{kg}$ & $15.85 \pm 1.34$ & $17.67 \pm 0.41$ & $18.46 \pm 0.73$ & $18.97 \pm 2.15$ \\
\hline $\begin{array}{c}\text { G5 } \\
(n-5)\end{array}$ & Extract $200 \mathrm{mg} / \mathrm{kg}$ & $15.83 \pm 1.14$ & $16.27 \pm 0.73$ & $17.55 \pm 0.41$ & $19.62 \pm 0.76$ \\
\hline
\end{tabular}

G1 - Normal control, G2 - Anemic control, G3 - Standard drug control, G4 - Dosage 1, G5 - Dosage 2

Table 13. Comparative mean scores for overall acceptability of snacks using $P$. serratifolia leaf powder

\begin{tabular}{|c|c|c|c|}
\hline \multirow{2}{*}{ Formulated products } & \multicolumn{3}{|c|}{ Variations Mean \pm SD } \\
\cline { 2 - 4 } & S & S1 & S2 \\
\hline Biscuit & $4.44 \pm 0.65$ & $4.40 \pm 0.49$ & $4.32 \pm 0.41$ \\
\hline Vadam & $4.73 \pm 0.41$ & $4.56 \pm 0.34$ & $4.45 \pm 0.47$ \\
\hline Murukku & $4.65 \pm 0.57$ & $4.58 \pm 0.45$ & $4.11 \pm 0.69$ \\
\hline
\end{tabular}

S - Standard

S1 - 10:0.5 (wheat flour :P.serratifolialeaf powder)

10:1 (rice flour :P.serratifolialeaf powder)

10:0.5 (rice flour :P.serratifolialeaf powder)

S2 - $\quad$ 10:1 (wheat flour :P.serratifolialeaf powder)

10:2 (rice flour :P.serratifolialeaf powder)

10:1 (rice flour :P.serratifolialeaf powder) 
dard murukku for mean overall acceptability. Further, the overall acceptability scores of $\mathrm{S}$ for all formulated snacks received highest scores than S2. The least score for overall acceptability was obtained by $\mathrm{S} 2$ murukku. Hence addition of higher proportion of $P$. serratifolia leaf powder affects the overall acceptability scores of the product irrespective of the type of snacks.

\section{Conclusion}

From the above research, it can be concluded that $P$. serratifolia leaf contains iron, phosphorus, calcium and ascorbic acid. The leaf extract of $P$. serratifolia had higher impact of hematological parameters when compared with standard drug ferrous fumarate. Hence, the higher dosage (200mg) of $P$. serratifolia leaf extract has immediate and high response than the lower dosage. By using $P$. serratifolia leaf powder in various snacks could be formulated for easy consumption in day to day life. The higher incorporation of $P$. serratifolia leaf powder helps to increase the nutrient content in formulated snacks.

\section{References}

1. Biradar SS, Biradar SP. Alatagi AC, Wantamutte AS and Malur PR. Prevalence of anemia among adolescent girls, a one year cross sectional study, Journal of Clinical and Diagnostic Reasearch. 2012; 6(3):372-7.
2. Zhang AS and Enns CA. Molecular mechanisms of normal iron homeostasis. Hematology American Society, Hematology Education Program. 2009; 1:207-14.

3. Pandey M, Rohit K, Verma and Shubhini AS. Nutraceuticals new era of medicine and health. Asian Journal of Pharmaceutical and Clinical Research. 2010; 3(1):1115.

4. Biesalski HK. Nutraceuticals: The link between nutrition and medicine. Kramer K, Hoppe PP, Pocker L, editors. Nutraceuticals in health and diseases prevention New York. Marcel Dekker. 2001; p. 1-26. https://doi. org/10.1201/9780203908174.ch1. PMid:11370660

5. Rekha R. Antimicrobial activity of different bark and wood of Premna serratifolia Lin. 2010. International Journal of Pharma and Bio Sciences. 2010; 6(1):1-9.

6. Warrier PK, Nambiar VP, Ramankutty C. Indian Medicinal Plants. A compendium of 500 species, India. Orient Longman Publications. 1995; 4:348-52.

7. Kala SMU, Balasubramanian T, Soris $\mathrm{T}$ and Mohan VR. GC-MS determination of bioactive components of Eugenia singampattianaBedd. International Journal of ChemTech Research. 2011; 3:1534-7.

8. Singh RC. Antimicrobial effect of callus and natural plant extracts of premnaserratifolia L. International Journal of Pharmaceutical and Biomedical Research. 2011; 2:1720.

9. Selvam TN, Venkatakrishnan V, Damoder KS, Elumalai P. Antioxidant and tumor cell suppression potential of Premnaserratifolia Linn. leaf. Toxicology International. 2012; 19:31-4. https://doi.org/10.4103/0971-6580.94514. PMid:22736900 PMCid:PMC3339242 